\title{
Long-term monitoring on the occurrence of a myxosporean parasite Kudoa camarguensis (Myxosporean) on the common goby (Teleostei, Pisces) Pomatoschistus microps
}

\author{
C. Pampoulie ${ }^{1,2,3, *}$, A. Marques ${ }^{4}$, E. Rosecchi ${ }^{1}$, J. L. Bouchereau ${ }^{5}$, A. J. Crivelli ${ }^{1}$ \\ ${ }^{1}$ Station biologique de la Tour du Valat, Le Sambuc, 13200 Arles, France \\ ${ }^{2}$ Laboratoire Ecosystèmes Lagunaires, Université Montpellier II, Sciences et Techniques du Languedoc, CC093, \\ Place E. Bataillon, 34095 Montpellier cedex 5, France \\ ${ }^{3} \mathrm{KU}$ Leuven, Laboratory of Aquatic Ecology, Ch. de Bériotstraat 32, 3000 Leuven, Belgium \\ ${ }^{4}$ Laboratoire de Parasitologie et Immunologie, Université Montpellier II, Sciences et Techniques du Languedoc, \\ Place E. Bataillon, 34095 Montpellier cedex 5, France \\ ${ }^{5}$ Université des Antilles et de la Guyane, Faculté des Sciences exactes et Naturelles, Laboratoire de Biologie Animale, \\ Guadeloupe, BP 592, 97159 Pointe-à-Pitre cedex, France
}

\begin{abstract}
The evolution of a host-parasite system composed of Pomatoschistus microps-Kudoa camarguensis was investigated in the Vaccarès lagoon (Rhône river Delta, France) from 1993 to 1997. During this long-term monitoring, centennial flooding of the Rhône river occurred, leading to an inrush of about 110 million $\mathrm{m}^{3}$ of freshwater in the Vaccarès lagoon. The salinity drastically dropped from 14 to $5 \mathrm{~g} \mathrm{l}^{-1}$ in $1 \mathrm{wk}$. We observed that the annual prevalence and abundance of the myxosporean parasite decreased from 12.18 in 1993 to $3.7 \%$ in 1997 and from 1.10 in 1993 to 0.27 in 1997 , respectively. Here, we discuss the possible reasons for the rapid decline of this host-parasite system following the flood.
\end{abstract}

KEY WORDS: Myxosporea $\cdot$ Kudoa $\cdot$ Prevalence $\cdot$ Abundance $\cdot$ Salinity stress

Resale or republication not permitted without written consent of the publisher

\section{INTRODUCTION}

While studying Gobiidae populations (Teleostei; Pisces) in the Vaccarès coastal lagoon (Rhône river delta, France) from 1993 to 1997, we detected many white spindle-shape bodies in a sedentary goby species, Pomatoschistus microps (Krøyer, 1838), and in a migratory one, P. minutus (Pampoulie et al. 1999). Those spindle-shape bodies turned out to be a new species of Myxosporean parasites which belongs to the genus Kudoa, which we named Kudoa camarguensis (Pampoulie et al. 1999). In the winter of 1993 to 1994, centennial flooding of the Rhône river broke the artificial levees surrounding the delta, which led to an

*E-mail: pampoulie@univ-montp2.fr inrush of about 110 million $\mathrm{m}^{3}$ of freshwater in less than $1 \mathrm{wk}$. This resulted in a rapid and sharp salinity drop (from 14 to $5 \mathrm{~g} \mathrm{l}^{-1}$ ) in the Vaccarès. This drop in salinity and its maintenance at around $5 \mathrm{~g} \mathrm{l}^{-1}$ in the following years have affected benthic organisms like polychaetes and oligochaetes (Pampoulie et al. 1998) which are suspected to be the intermediate hosts in other Myxosporea species (Benajiba \& Marques 1993, Uspenskaya 1995, Bartholomew et al. 1997). As we had been monitoring fish in the system since 1993, this sudden and sharp salinity change affecting the whole biocenosis offered a unique opportunity to study the evolution of a host-parasite system in a changing environment. We made the null hypothesis that environmental changes and the maintenance of low salinity affected the host-parasite system Pomatoschistus microps-Kudoa camarguensis for $5 \mathrm{yr}$. 


\section{MATERIALS AND METHODS}

The Vaccarès lagoon covers 6400 ha. The maximum depth is $2 \mathrm{~m}$ and the mean annual salinity was $13.6 \mathrm{~g}$ $\mathrm{l}^{-1}$ in 1993 and $5.2 \mathrm{~g} \mathrm{l}^{-1}$ in 1997. Monthly sampling was conducted from March 1993 (7 mo before the floods) to December 1997 for 4 consecutive days per month. For technical reasons, samples were only collected for a few months in 1996 and no biological study was done. Fyke nets ( $6 \mathrm{~mm}$ mesh size) and fry fyke nets $(0.5 \mathrm{~mm}$ mesh) were visited every day. Fish were preserved in $10 \%$ formalin. As white spindle-shape bodies of Kudoa camarguensis were visible to the naked eyes (Pampoulie et al. 1998), fishes were examined macroscopically and parasite bodies counted under a light microscope. Total length (TL in $\mathrm{mm}$ ) was measured on each fish $(22 \mathrm{~mm}<\mathrm{TL}<53 \mathrm{~mm}$ ). To determine the trends of annual prevalence (number of parasitized hosts/number of hosts examined) and abundance (number of parasites/number of hosts examined) in relation with the sampling years, we tested linear and non-linear regressions and chose the regression which explained the highest percentage of variation. The distributions of monthly prevalence of the 'standard' year (1993) were compared with those observed the following year using a Wilcoxon-Mann-Whitney $U$-test.

\section{RESULTS}

In total, 2980 common gobies were examined and 196 were found to be parasitized $(6.58 \%)$. Trends of annual prevalence (Fig. 1) were fitted to a polynomial regression model $(\mathrm{r}=0.99, \mathrm{n}=4, \mathrm{p}=0.01)$ as well as annual abundance $(\mathrm{r}=0.97, \mathrm{n}=4, \mathrm{p}=0.01)$. In the Vaccarès, the distribution of monthly prevalence (Fig. 2) was not different between 1993 and 1994 for both females and males, whereas a significant difference was found between 1993 and 1997 (Table 1).

\section{DISCUSSION}

Our results clearly show the decrease of the number of fishes affected by Kudoa camarguensis in the Vaccarès lagoon following the sudden freshwater inflow of the winter 1993 to 1994. Annual prevalence of the host-parasite system decreased drastically between 1993 and 1995, and remained at around $4 \%$.

The cycle of the Kudoa sp. is unknown, but annelids are suspected to be the intermediate hosts as in other

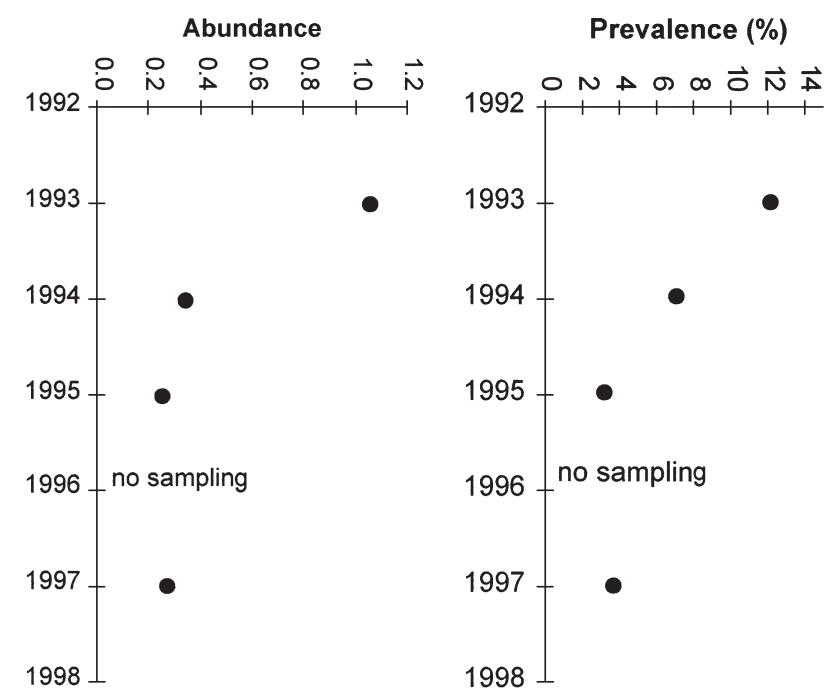

Fig. 1. Trends of annual prevalence of Kudoa camarguensis in the Vaccarès lagoon from 1993 to 1997

myxosporean parasites (Benajiba \& Marques 1993, Uspenskaya 1995, Bartholomew et al. 1997). In the Vaccarès lagoon, the polychaetes density decreased from between 340 and 1690 ind. $\mathrm{m}^{-2}$ in 1988, to between 30 and 233 ind. $\mathrm{m}^{-2}$ in 1997 (Pampoulie et al. 1998). Conversely, the number of oligochaetes increased from 0 ind. $\mathrm{m}^{-2}$ in 1988 (Ximenes et al. 1989), to between 11 and 444 ind. $\mathrm{m}^{-2}$ in 1997 (Pampoulie et al. 1998). We believe that this decrease in prevalence in the Vaccarès lagoon could be explained by the decrease of the polychaetes, which are suspected to be the intermediate host of $K$. camarguensis. Moreover, only 2 polychaetes species were present in the system from 1993 to 1997, namely Streblospio shrubsolii and Heteromastus filiformis (Pampoulie 1999). Thus, this host-parasite system probably involves 1 of these 2 
Table 1. Comparison of the monthly distributions of prevalence for Kudoa camarguensis in the Vaccarès from 1993 to 1997. Values for males are above the diagonal; values for females are below the diagonal. ns: not significant; $U$ : Wilcoxon-Mann-Whitney parameter value; $z$ : variance of $U$

\begin{tabular}{|c|c|c|c|c|}
\hline${ }_{\text {Females }}^{\text {Males }}$ & 1993 & 1994 & 1995 & 1997 \\
\hline 1993 & & $\begin{array}{c}U=49.5 \\
Z=1.32 \\
\mathrm{~ns}\end{array}$ & $\begin{aligned} U & =26.5 \\
z & =2.96 \\
\mathrm{p} & =0.003\end{aligned}$ & $\begin{aligned} U & =37.5 \\
Z & =2.11 \\
\mathrm{p} & =0.03\end{aligned}$ \\
\hline 1993 & $\begin{array}{c}U=61 \\
Z=0.64 \\
\quad \mathrm{~ns}\end{array}$ & & $\begin{aligned} U & =239 \\
z & =2.56 \\
\mathrm{p} & =0.02\end{aligned}$ & $\begin{array}{c}U=47 \\
z=1.56 \\
\text { ns }\end{array}$ \\
\hline 1993 & $\begin{aligned} U & =35.5 \\
z & =2.16 \\
\mathrm{p} & =0.03\end{aligned}$ & $\begin{array}{c}U=42 \\
Z=1.76 \\
n s\end{array}$ & & $\begin{array}{c}U=66.5 \\
Z=0.76 \\
\mathrm{~ns}\end{array}$ \\
\hline 1993 & $\begin{aligned} U & =37.5 \\
z & =2.11 \\
\mathrm{p} & =0.03\end{aligned}$ & $\begin{aligned} U & =36 \\
Z & =2.16 \\
\mathrm{p} & =0.04\end{aligned}$ & $\begin{array}{c}U=62.5 \\
Z=0.67 \\
\text { ns }\end{array}$ & \\
\hline
\end{tabular}

annelid species. We think that the occurrence of oligochaetes, which were not found in 1993 in the Vaccarès, cannot explain the observed prevalence. Nevertheless, these sporadic results are definitively less informative than long-term monitoring of benthic populations would have been; therefore, further investigations are required to confirm this hypothesis. Moreover, recent studies have demonstrated the capacity of some species of myxosporean parasites to infect fish directly, with no need of an intermediate host or other vector (Diamant 1997).

In conclusion, this is the first time that a long-term study including a change in environmental parameters could be carried out on a species belonging to the genus Kudoa. Our data clearly highlighted that $K$. camarguensis prevalence strongly decreases in low salinity and suggested that its cycle probably involved a polychaete to be found among the 2 following species: Streblospio shrubsolii and Heteromastus filiformis. Nevertheless, as the cycle of this species is

Editorial responsibility: Wolfgang Körting,

Hannover, Germany unknown, our hypothesis must be regarded as speculative as long as salinity-sensitive annelids have not been shown to act as intermediate hosts.

Acknowledgements. This study was conducted within the framework of a CIFRE agreement between the Biological station of Tour du Valat and the Laboratory of Lagoonal Ecosystems of the University Montpellier II, awarded to C. Pampoulie for his doctoral study. We thank Mr E. Coulet, Director of the Réserve Nationale de Camargue, for allowing us to conduct monthly sampling in the Vaccarès and P. Contournet, F. Priour and O. Soulas for their help in the field. We thank Dr I. Auby for sorting out and identifying the benthic samples.

\section{LITERATURE CITED}

Bartholomew JL, Whipple MJ, Stevens DG, Fryer JL (1997) The life cycle of Ceratomyxa shasta, a myxosporean parasite of salmonids, requires a freshwater polychaetes as an alternate host. J Parasitol 83:859-868

Benajiba MM, Marques A (1993) The alternation of actinomyxidian and myxosporidian sporal forms in the development of Myxidium giordi (parasite of Anguilla anguilla) through oligochaetes. Bull Eur Assoc Fish Pathol 13: 100-103

Diamant A (1997) Fish-to-fish transmission of a marine myxosporean. Dis Aquat Org 30:99-105

Pampoulie C (1999) Conséquences d'une arrivée massive d'eau douce sur la communauté de gobies (Téléostéens, Pisces) d'une lagune méditerranéenne: l'exemple de l'Etang du Vaccarès (Camargue, France). PhD thesis, University Montpellier II

Pampoulie C, Marques A, Rosecchi E, Crivelli AJ, Bouchereau JL (1998) First record of Kudoa (Myxosporea) in Pomatoschistus microps in the Rhône delta, France. J Fish Biol 53:893-896

Pampoulie C, Marques A, Rosecchi E, Crivelli AJ, Bouchereau JL (1999) A new myxosporean parasite, Kudoa camarguensis n. sp. recorded on two goby species (Teleostei: Pisces) in the Rhône Delta (Mediterranean Sea, France). J Eukaryot Micro 46:304-310

Uspenskaya AV (1995) Alternation of actinosporidian and myxosporean phases in the life cycle of Zschokkella nova (Myxozoa). J Eukaryot Microbiol 42:665-668

Ximenes MC, Sagliocco M, Frisoni GF, Labourg PJ (1989) Etude écologique des étangs centraux de la Camargue: le Vaccarès et les Impériaux. CEMAGREF

Submitted: April 10, 2000; Accepted: January 19, 2001 Proofs received from author(s): April 20, 2001 